\title{
FEMALE MONASTICISM IN THE SOC - THE EXAMPLE OF THE LIPOVAC MONASTERY
}

UDC 271.2-788-055.2(497.11)

\section{Dragana Zaharijevski, Danijela Gavrilović}

University of Niš, Faculty of Philosophy, Department of Sociology, Niš, Serbia

\begin{abstract}
This paper problematizes certain topics related to female monasticism in the Serbian Orthodox Church. Since the mere phenomenon of female monasticism and the practice present in this region are very rich, we were inclined to focus on specific aspects of the monastic life: the identity of nuns and the relation towards marriage and family.
\end{abstract}

Key words: Female monasticism, SOC, identity, marriage, family.

\section{ON MONASTICISM IN GENERAL}

Monasticism is believed to be an authentic expression of the church experience, a solemn phenomenon of asceticism, a dynamic path of love of God - with the activities that take place in the rhythm of divine service and constant liturgy; monasticism is a blessing which is not primarily an escape or renunciation - the essence lies in acceptance, the gift from God, in putting all of our relations into the personality of Christ, thus - "by not having anything possessing all". ${ }^{1}$ Monasticism is a distinctive and highest form of Christian life, resting on particular monastic vows, such as the vow of poverty, obedience and chastity, based on the presupposition of distancing oneself from the world and relinquishing worldly values. "Sublime and noble, the known ideal of the monks implied a continuous process of self-improvement and a perennial struggle to climb the ladder to virtue. Monastic daily life, with its peculiar rhythm, regime of services and obediences, was thus conceived precisely to encourage and facilitate this struggle" (Marjanović Dušanić and Popović 2004, 552). Understood and adopted in this way, monasticism does

Received July 12, 2016 / Accepted July 21, 2016

Corresponding author: Danijela Gavrilović

University of Niš, Faculty of Philosophy, Cirila i Metodija 2, 18000 Niš, Serbia

E-mail: danijela.gavrilović@ filfak.ni.ac.rs

${ }^{1}$ From the talks delivered at the international scientific and spiritual symposion "On Female monasticism", held in the Holy Monastery of Žiča, in September 2011, on the occasion of the eight-hundredth anniversary of the monastery. Around thirty lecturers from Greece, Russia, Cyprus, France, Syria, Georgia, as well as Orthodox dioceses of the Serbian Church from the country and abroad, participated in the meeting (Žiča monastery 2014, Scientific and spiritual symposion on female monasticism (video footage), Žiča, Fondacija Nasleđe, Belgrade). 
not recognize the differences between the male and female monastic life; however, it does pose certain questions and requires explanations and so this paper, among other things, is a product of a dialogue led by the people found on the opposite side of the monastery wall. The paper is based on 1) the talks given at the international scientific and spiritual symposium "On Female Monasticism", held in the Holy Monastery of Žiča, and 2) the records of the performed in-depth interviews, carried out in the Lipovac monastery. ${ }^{2}$

\title{
2. Female MonASTICISM - CHOICE AND ESSENCE
}

\begin{abstract}
"According to church regulations, any grown person can become a monastic, regardless of their sex, education, greatness of moral values and previous life, since the life of a monastic is a life of penitence."
\end{abstract}

Patriarch Pavle

Female monasticism is a phenomenon present in many religious traditions. Within Christianity both eastern and western female monasticism have had a long tradition, with nuns very often coming from aristocratic circles and being educated and performing numerous important social roles such as caring for the sick, poor, or children, copying manuscripts, translating, taking care of libraries and schools (Western Civilisation: A Brief History, 208, Manastir Žiča). Female monasticism was widespread in the eastern tradition, with known examples of women from the ruling families who spent their lives in monasteries taking the monastic veil. In this region as well, within the Orthodox tradition, female monasticism was linked with the members of aristocratic families in the $11^{\text {th }}$ century, as well as later on after the new initiative during the reign of the Nemanjic dynasty. The first girls' schools were opened in monasteries. (The Gradac monastery is an endowment of Queen Helen of Anjou, wife of King Stefan Uroš I. The monastery, dedicated to the Annunciation, was constructed around 1270. The Queen established the first female school there.) Female monasticism has had a long tradition within the SOC, with the number of nuns varying over time until the $18^{\text {th }}$ century when a discontinuity occurred in 1774 with the closing of the last female monastery Stari Jazak in Vojvodina, only for female monasticism to be revived in the south of Serbia in the middle of the $19^{\text {th }}$ century, as well as in the $20^{\text {th }}$ century with the arrival of Russian nuns, when the tradition of female monasticism in Serbia was fully renewed.

\footnotetext{
2 The Lipovac Monastery is located in the vicinity of Aleksinac. It was built in the $14^{\text {th }}$ century, close to the Leskovik rock. Back then, the spot where the monastery is today was occupied by Lipovac Town, and the local nobleman, who ruled the fortification, built a church on his land. A couple of decades later, the church was transformed into a monastery, which was first dedicated to Saint Stefan, while today it is dedicated to the Transfiguration of Christ. The monastery was first inhabited by the monks from the southern parts of the Serbian empire, who fled before the advancing Ottomans. Since 1974 the Archimandrite Dionisije has been Father Superior of the Lipovac monastery, and he is the person responsible for its renovation. The monastery has been under the protection of the state since 1982 as a cultural monument of outstanding importance.

There are 13 nuns at the moment in the monastery, and they primarily perform the spiritual activities by participating in worshipping services and prayers, as well as other obediences related to the correspondence with the believers and various everyday chores in the monastery. Father Dionisije emphasizes the fact that the number of nuns is constantly decreasing, which he explains by fewer and fewer children being born in this region.
} 
One of the major questions being posed here is the issue of motivation behind such a life path. The assumption that the only true motive is the love of God is single-minded, while lay prejudice - such as disappointment in life, unsuccessful relationships and similar reasons, can soon turn out to be motives which are wrong and often do not lead to a permanent monastic life. This is why there exists a period of temptation that usually lasts for three years, during which the motives and strength of the person determined to take the monastic path are reconsidered. Therefore, the choice of monasticism is the choice of life. "First a man returns to God, the living and the true, and then to his genuine and true self. Renouncing the world is not its negation - it is not a cowardly escape, but rather a turn towards Christ. In the congregation communion one's own existence is subordinated to the community and that is where one finds freedom" (His Grace Bishop Teodosije of Ras and Prizren). Apart from this freedom, one can find luck there as well: "A man's greatest happiness is to find God - to find God in himself and in the others" (Mother Nektarija, Lipovac).

The essence of female monasticism lies, as Mother Pavla states, in the following: "A specific personal life, that is, a life without personal relations; Every relation of a nun should be established through God; A nun is a bride promised to Christ, a servant of God without any personal goals or inclinations, always open to God's will; The congregation life, that is, the life in the Church, started by the Church, ends in the Church and belongs to the Church; The spiritual life - meaning started by the holy spirit, and perfected through faith and repentance and the spirit, this life is guided by Son the Christ through the Spirit towards the Father" (Mother Pavla, Mother Superior of the Petropavlovo monastery, Herzegovina, 2014), while the decision on monasticism is reached when a person feels their sin with their entire being.

It can be concluded from the above that a nun, driven by faith, directs her attention to a different reality which provides her with a twofold achievement through penitence: to cast off evil and accept good. Mother Nektarija emphasizes that this can be achieved through humbleness and obedience: "we come to the monastery of our own free will", our interviewee says, "I came here fully aware of it and highly motivated, not because I was disappointed in life. The ones that begin this journey for such reasons - disappointed in the world, disappointed in their love choice, or something else, soon realize that they are at the wrong address, because one cannot live in a monastery out of disappointment. Nowhere really, not only here. If we can fulfil two of God's greatest commandments: to love God, and then to love our neighbour - we are given freedom, freedom from sin. This is how we get closer to Christ! God always respects free will - He waits for every man to repent for himself, and then responds to each repentance with forgiveness! There is freedom in the monastery if we know that the freedom from sin is the greatest. We are summoned to better ourselves so that we can live, and not sin. We are not sinless as God. The greatest treasure a person can possess is the peace in their soul. And if we follow God's law, fulfil God's commandments, we bear the burden of God with ease, we obey God's law, Mother Superior and the spiritual father in the monastery, and this burden does not fall heavy on us at all" (Mother Nektarija, Lipovac). 


\section{IDENTITY OF NUNS}

The theoretical context of examining the identity of nuns is positioned, above all, within a sociological determination, according to which identity is "the process of creating meaning on the basis of cultural attributes or a related sequence of cultural attributes which have the advantage over the other sources of meaning" (Castells 2002, 16). Therefore, it is important for people to understand themselves and that which they find significant. The phenomenon of female monasticism inevitably implies the consideration of sex and gender as key indicators of identity, forms of personal expression, but also unique constructs. Judith Butler, a theoretician of post-feminism, within the concept of "contingent foundations" and "the performativity of gender and sex", talks about discursive limitations of sex and emphasizes that the category of sex is normative from the start: “"sex' not only functions as a norm, but is part of a regulatory practice that produces the bodies it governs [...] Thus, 'sex' is a regulatory ideal whose materialization is compelled, and this materialization takes place (or fails to take place) through certain highly regulated practices" (Butler 2000). Thus, identity becomes a narrative which is transformed in light of new circumstances - it is a description of our very own selves. It is a process which gives certain meaning to the most diverse events, whereby life, world, and reality acquire some sense (Berger and Luckmann 1992). Hence, this "significance" directs towards the dimensions of identity (Zaharijevski Stjepanović 2010, 101-116).

Within the context of examining the monastic life "where God and man are present, and in which, despite belonging to the present both time and space are sanctified through a monk's, an ascetic's directedness towards the eternal, i.e. through constant orientation towards the heavenly kingdom" (Mother Pavla, Mother Superior of the Petropavlovo monastery, Herzegovina, 2014), the issues of sex/gender take on a new relevance and direct us towards the specific frameworks of the "significant" in the identification and selfidentification of nuns.

\subsection{Servant and bride of God}

"A nun is a servant and bride of God. She lives and breathes through Jesus' prayer, the praying rules of the cell, and service in the Temple. Nuns live as dispersed God's children collected into one in Christ. The life in Christ means putting all of our relations through which we acquire our identity into one. The meaning of a nun's personality is getting closer to the image of God" (Mother Pavla). "The life in Christ for a nun means no marriage" (His Grace Bishop Teodosije of Ras and Prizren). "By taking the veil and living a life without marriage - we dedicate all of our energy and time to God" (Mother Nektarija, Lipovac). Among nuns one can even find women who were once married, who have grown children, but with no obligations towards them, as well as those who led an "immoral" secular life, so their monastic life provides them penitence. ${ }^{3}$

Marriage and monasticism are essentially the same (Bishop Hilarion Alfejev). "These are not two different paths, but two paths which are to a great extent close to one another. Man as an individual - a being, is only fully worthy if he realizes himself as a person who communicates with others. In marriage as well the fulfilment of what is lacking is

\footnotetext{
${ }^{3}$ In the Byzantine Empire the practice was to lock away adulterous women in monasteries (Konstantin Picakis, Žiča, 2014).
} 
obtained by acquiring the other "half", the other "I", by acquiring the "other". In monasticism this "other" one is God himself" (Žiča monastery, video footage).

\subsection{Sex/gender characteristics}

The Christian tenet of equality before God is expressed to the greatest extent in monasticism. What separates us from each other - anatomy, physical appearance and giving birth, completely loses all meaning in a monastery. However, the differences in what is available to nuns and monks still remain.

From Paul the Apostle's Epistle to the Corinthians, we get to know that there is no male or female in Jesus Christ, no division in any sense whatsoever, and that we all are one. Every person has been given a soul by God. The soul is sexless. "Both monks and nuns take the vow before God and offer themselves to God for eternity. In monastic life, the most important thing is that a monk dwells in the love of Christ, which is mainly expressed through everyday worship" (His Grace Bishop Teodosije of Ras and Prizren, 2014).

Even though sex differences are negated at the dogmatic and theoretical level, this is not also the case in everyday life since the monastery life acknowledges and respects the sex/gender hierarchy and distribution of roles. Thus, in the church and monastery hierarchy, certain positions are not available to nuns: nuns cannot perform liturgy and other clerical functions, so it is necessary that every female monastery have a spiritual father who conducts confessions and communion in the monastery. ${ }^{4}$ Mother Nektarija from the Lipovac monastery provides an explanation of such practice, quoting the words of Bishop Danilo Krstić Budimski: "here on earth nuns are indeed deprived, if we look at it formally, of performing the sacred liturgy, having the rank of priest or archimandrite in a monastery, bishop or patriarch as the highest rank in the hierarchy - which belongs to men and is a great honour, but on the other hand a great responsibility as well. The essential responsibility is much greater." To the question posed by the authors on whether a woman is truly not able to carry such responsibility, Mother Nektarija answers: "It is not a question of whether she can or cannot do it - there is God's law, there are rules. Women are not deprived of anything, on the contrary - the Holy Mother of God, who is female, the first to God, the closest to Him, is an expression of Angels, even closer than all Angels, bishops, reverends who once lived or are alive now - meaning the closest to God. Since the Holy Mother of God is the closest to God and most honoured despite men being more subject to honour and government on earth - men cannot ever reach the honour that the Mother of God enjoys. This blessedness is no one's but hers. The Holy Mother of God is the representative of the entire humanity, and women as well. On equality - Bishop Danilo used to say - if a woman does not complain about her position, if she is obedient, regardless of what she does, she will be honoured by the same blessedness as the Mother of God - she will be above all men who are honoured here to be at the top of the hierarchy, yet one should know that this worldly hierarchy is not the same as the one in heaven. There is female and male monasticism, but there are no divisions. There is no difference in the spiritual sense, although there are some in the roles, which are not problematic. We get different assignments. Mother Superior sets the obediences, organizes us. So monasticism can be compared to a beehive which functions impeccably because everyone has a role, everyone is diligent, hard-working - nobody

\footnotetext{
${ }^{4}$ It was discussed in the Code of Justinian whether these should have been eunuchs or the elderly (Konstantin Picakis, Žiča, 2014).
} 
complains about anyone else, everyone has their own tasks. God created both man and woman. God created Adam and Eve. God is the creator of one and the other. There is no reason for women to feel handicapped. We have to work on bringing people together, on keeping them in a community. There is no need to meddle in things, force something that is not there. I absolutely do not feel deprived of anything just because I am a woman. The advantage is to have a smaller role, less responsibility - that is an easier path to salvation. I truly believe that women, if they do not break God's law, and do not sin, if they do what is necessary to a satisfying degree - by the mercy of God, not our own credit, by believing in God, we will be in the company of the Holy Mother of God who is the closest to God despite all the men that are so important and powerful now"(Mother Nektarija, Lipovac).

There is no doubt that "female anatomy differs from that of the male. There also exists a biological imperative to reproduce; otherwise, the human species would become extinct" (Giddens 2003, 135). This imperative is linked with women. The exclusive connectedness between giving birth and women, in E. Badenter's opinion, implies the reduction of a woman's identity to the power of giving birth (Badenter 1988). Women have been given this gift by God, so many believe that the meaning of their life lies exactly in childbirth. On the other hand, "a nun is a bride promised to Christ, a servant of God without any personal goals or inclinations, always open to God's will, relinquishing marriage and childbirth by choosing monasticism" (Mother Pavla, Mother Superior of the Petropavlovo monastery).

The authors wanted to know what the nuns who gave up childbirth thought about what was said above. One of the explanations was provided by Mother Nektarija (Lipovac): "Had not Adam and Eve sinned in Heaven, God had other plans for them, another plan for the multiplication of humanity. Everything is possible for God. Since he was able to create the first man from the dust of the earth, he could have created a million people, but the fact that Adam and Eve sinned, led them to carry that cross - they were cast out of Heaven, and according to Paul the Apostle, Eve was told - you will bear children in pain, but you will save yourself through childbirth and by remaining in faith! On the other hand - if a woman fulfils her destiny here on earth - if she becomes a mother, if she marries, if she prays to God all the time, not complaining about being female, if she is a good mother, even more if she is a mother of many children, and if she lives to see them grow up, become good people, if she witnesses the fruit of her love and energy - there will be nothing more joyous. That is a gift from God! A mother is obliged to sacrifice for her children. God demands a sacrifice from each of us. People are often handicapped by a hedonistic philosophy of life - nobody entered the Kingdom of Heaven by cutting corners. You cannot enter without sacrificing something. The point is to understand the sacrifice of the mother who gave birth to us and raised us. When we sacrifice for someone else we fulfil what was meant by God. We are given the possibility to direct all of our energy, to make an effort on someone else's behalf and help them - because it is then that the image of God in us truly comes to life."

By entering the monastic life, a nun necessarily changes her relation towards physical appearance, beauty, clothing, and leads a smaller or a bigger battle with vanity and arrogance. Spiritual beauty is what matters. On this topic Mother Nektarija says the following: "What does it mean paying attention to beauty? All of that will end up in a grave one day. If that was the meaning, God would have given us a lasting beauty. So - the meaning is in spiritual beauty (it cannot be lost, it cannot be stolen from you) - Be rich in God! Bishop Danilo, a man of pronounced theological depth, said that 'the more you have God in yourself the more agreeable you are to the people around you, the easier they can cooperate with you, you become a better man in every aspect!' So how do we fight vanity, arrogance? The answer 
lies in realizing that everything we have has been given to us by God! If anything is good - thank God. It came from Him. He is good and perfect. We can all just come closer to that pattern through prayer, through different patterns of conversing with God, as sincerely as possible and from the heart. Vanity is repressed in the monastery, arrogance is cured by obedience. If I was given a female body, that is the mercy of God, and the Lord will give me the strength to carry that burden and the cross of the female body. Every body has its own cross and responsibility, but also good sides - certain honours. It is a gift from God, just like any other talent that we possess. All of that has been given to us, all of it is the energy of life and everything that we have came from God and for that purpose again - In the glory of God, to our neighbours for use, and to us for salvation!" (Mother Nektarija, Lipovac).

Similar to this explanation is the statement by Mother Superior of the Petropavlovo monastery, who believes that a nun abstains and removes herself from specific attractiveness, not because she has a negative attitude towards nature, but so that she can remain unshackled by that beauty and capable of loving all people, even the ones who are not attractive. "That is why the monastery is ruled by penitence, prayer and other virtues which transform the relations into the ones based on the spiritual and conscious appreciation of the other as an inseparable part of one's own personality" (Mother Pavla).

\subsection{Biological and spiritual family}

By coming to the monastery, nuns leave their biological families, and the question is how they experience their monastic community - as a new family or a completely different entity.

"Nuns are the ones who possess all by having nothing, who acquire a much wider, more genuine family than the biological one that has been left behind, and to this wider family, the biological family now belongs as well, although renewed, blessed and conceived in the monastic atmosphere of togetherness," which, among other things, stands for: "a deep, personal internal and congregational life of worship of each nun individually, and the entire coenobium; the building of a community and establishing relations based on penitence, obedience, love and prayer; the nurturing of the spirit of joy but also all other virtues: simplicity, sincerity, tameness, abstinence, perseverance, patience, hospitality, modesty, lordliness; presence at collective spiritual assemblies" (Mother Pavla, Mother Superior of the Petropavlovo monastery, 2014).

When Mother Nektarija came to the Lipovac monastery 19 years ago, she left her biological family, her parents and two sisters, with whom she remains in contact; however, she does not believe that she has substituted that family with another, spiritual one in the monastery. "Spiritual relatedness and blood relatedness are two different notions. You have fatherhood and parenthood. I have a dad, mom, but also the spiritual father Dionisije and Mother Superior - the spiritual mother. This cannot be equated. There are different feelings towards the ones and the others. I have not chosen my mom and dad, but I have chosen monasticism. I am a spiritual child of Father Dionisije." Despite being brought up in a traditional family in the spirit of faith, it was not until the studies in "atheist sociology", and owing to the spiritual dialogues with Patriarch Pavle and Bishop Danilo, that she made her final decision and chose the monastic way of life. 


\section{A FEW ENDING NOTES}

Female monasticism is, indeed, an ascetic and most profound form of Orthodox confession, as is the case in other religions as well. Nuns have for centuries performed important charity activities in society. However, the key to their existence lies in the spiritual convergence with God through the renunciation of passion, needs and desires of everyday life. The female body is a given which is not negated, but it is of no significance whatsoever to the identity of nuns and the path to God which represents an alternative to the usual female existence guided by childbirth and marriage.

Acknowledgement: Prepared as a part of the project Sustainability of the Identity of Serbs and National Minorities in the Border Municipalities of Eastern and Southeastern Serbia (179013), conducted at the University of Niš - Faculty of Mechanical Engineering, and supported by the Ministry of Education and Science of the Republic of Serbia.

\section{REFERENCES}

Badinter, Elisabeth. Jedno je drugo. Sarajevo: Svjetlost, 1988.

Berger Peter L. and Thomas Luckman. Socijalna konstrukcija zbilje. Zagreb: Naprijed, 1992.

Berman Constance. H. Women and Monasticism in Medieval Europe: Sisters and Patrons of the Cistercian Reform

(TEAMS Documents of Practice Series). Kalamazoo, Michigan: Medieval Institute Publications, 2002.

Butler Judith. Nevolje s rodom. Zagreb: Ženska Infoteka, 2000.

Castells Manuel. Moć identiteta. Zagreb: Golden marketing, 2002.

Episkop Ilarion Alfejev: Vi ste svetlost sveta - O monaštvu. Preuzeto sa http://orthodoxia.org/hilarion/booksrus/ svet/mon.htm, 10. 5. 2016.

Gidens, Entoni. Sociologija. Beograd: Čugura print, 2003.

Greer Sarah Louise. Behind the Veil: The rise of female monasticism and the double house, https://researchspace.auckland.ac.nz/handle/2292/20320, 1. 6. 2016.

Manastir Žiča. Naučno-duhovni simposion o ženskom Monaštvu (video snimak). Žiča: Fondacija Nasleđe, 2014.

Marjanović Dušanić S. i D. Popović, prir. Privatni život u srpskim zemljama srednjeg veka. Beograd: Clio, 2004

Spielvoge, Jacson. J. Western Civilisation: A Brief History. Wadsworth Publishing; 8 edition, 2013.

Zaharijević, Andrijana. "Deregulacija temelja." Filozofska istraživanja 25, 4 (2005).

Zaharijevski Stjepanović, Dragana. Rod, identitet u razvoj. Niš: Filozofski fakultet, Punta, 2010.

\section{ŽENSKO MONAŠTVO U SPC - PRIMER MANASTIRA LIPOVAC}

Ovaj tekst ima za cilj da problematizuje neke teme vezane za žensko monaštvo u Srpskoj pravoslavnoj crkvi. Kako je sam fenomen ženskog monaštva i praksa prisutna na ovim prostorima veoma bogata bili smo prinuđeni da se fokusiramo na pojedine aspekte monaškog života: identitet monahinja, odnos prema braku i porodici.

Ključne reči: žensko monaštvo, SPC, identitet, brak, porodica. 